\title{
MODEL FOR IMPROVING THE EMPLOYEE PRODUCTIVITY THROUGH ISLAMIC LEADERSHIP AND INTERNALIZATION OF ISLAMIC WORK ETHIC IN SHARIA TOURISM (STUDY ON SHARIA HOTELS IN BANDUNG)
}

\author{
Imas Soemaryani \\ Universitas Padjadjaran, Indonesia
}

\begin{abstract}
This research aims to describe the Islamic leadership and internalization of Islamic work ethic implemented in the sharia hotels. Besides, this research tries to explore the effect of Islamic leadership and Islamic work ethic on the employee productivity in the sharia hotels in Bandung. The unit of analysis and observation in this research are employees of sharia hotels in Bandung. The sample was taken using a simple random sampling method, and the data were processed using the Partial Least Square (PLS), expected to describe the effect between the variables and the degree of the manifest variable in constructing the latent variable within the limited observation unit. The results showed that the Islamic leadership and internalization of Islamic work ethic in the sharia hotels in Bandung are strong. The Islamic leadership and Islamic values positively affect the productivity of the employees.
\end{abstract}

Keywords: Islamic leadership, employee productivity, Islamic work ethic, sharia hotel

\author{
MODEL PENINGKATAN PRODUKTIVITAS KARYAWAN MELALUI \\ KEPEMIMPINAN ISLAMI DAN INTERNALISASI ETIKA KERJA ISLAMIC \\ PADA PARIWISATA SYARIAH (STUDI PADA HOTEL SYARIAH DI KOTA \\ BANDUNG)
}

\begin{abstract}
ABSTRAK
Penelitian ini bertujuan untuk melihat bagaimana kepemimpinan islami dan internalisasi etika islami diaplikasikan di hotel syariah serta seberapa besar kepemimpinan islami dan etika kerja islami mempengaruhi produktivitas kerja karyawan di hotel syariah di Kota Bandung. Unit analisis dan unit observasi dalam penelitian ini adalah karyawan hotel yang berkatagori syariah di kota Bandung. Pemilihan sampel dilakukan secara acak sederhana, data diolah dengan menggunakan Parsial Least Squre (PLS), yang mampu memberikan gambaran keberpengaruhan antar variabel dan seberapa besar seatiap variabel manifesnya mampu mengkonstruk variabel latennya dengan unit observasi yang terbatas. Hasil penelitian menunjukkan kepemimpinan islami dan internaslisasi etika kerja islami yang pada hotel syariah di kota Bandung cukup kuat, kepemipinan islami dan nilai nilai islami berpengaruh positif dalam pembentukan produktivitas kerja karyawan.
\end{abstract}

Kata-kata Kunci: Etika kerja Islami, hotel syariah, kepemimpinan Islami, produktivitas karyawan.

Korespondensi: Dr. Imas Soemaryani, S.E., M.Si. Universitas Padjadjaran. Jln. Dipati Ukur No. 35 Bandung. Email: imas.soemaryani@unpad.ac.id

Submitted: August 2018, Accepted: September 2018, Published: September 2018

ISSN: 1412 - 3681 (printed), ISSN: 2442 - 4617 (online), Website: http://journal.feb.unpad.ac.id/index.php/jbm 
Jurnal Bisnis dan Manajemen, Volume 19, No. 2, September 2018, p. 122-139

\section{INTRODUCTION}

Sharia tourism is any tourism activities supported by the facilities and services provided by the society, businesses, and government where all processes are in line with the teaching of Islamic law (sharia). This type of tourism includes many elements such as travel companies, hotels, management of tourism destinations, and the tourists. Of those elements, the hotel is the critical aspect, and this must comply with the sharia, started from the provision of halal foods, prayer rooms, praying facilities, prohibition for unmarried couples, separation of facilities for men and women, and the right understanding of Islam among the employees and the leaders of the hotel. The hotel activities relate to the provision of services determined by the productivity of the employees when serving the tourists or visitors. Of the many factors affecting the productivity of sharia hotel, Islamic leadership and internalization of Islamic work ethic are expected to significantly contribute to the employee productivity. The problem is, the sharia hotels are not fully implementing the Islamic leadership and Islamic work ethic, resulting in the less optimum productivity of the employees.

The tourism sector in Indonesia is the fourth most significant contributors to the state revenue after oils and gases, coals, and palm oils. From 2009 to 2013, the tourism sector contributed 10.054 million US dollars to the state revenue. The ranks are shown in table 1 as follows:

Table 1 Ranks of tourism and other sectors on state revenue 2009-2013

\begin{tabular}{|c|c|c|c|c|c|c|c|c|c|c|}
\hline \multirow[b]{2}{*}{ Rank } & \multicolumn{2}{|l|}{2009} & \multicolumn{2}{|l|}{2010} & \multicolumn{2}{|l|}{2011} & \multicolumn{2}{|l|}{2012} & \multicolumn{2}{|l|}{2013} \\
\hline & Commodity & $\begin{array}{l}\text { Value (Million } \\
\text { US\$) }\end{array}$ & Commodity & $\begin{array}{l}\text { Value (Million } \\
\text { US\$) }\end{array}$ & Commodity & $\begin{array}{l}\text { Value (Million } \\
\text { US\$) }\end{array}$ & Commodity & $\begin{array}{l}\text { Value (Million } \\
\text { US\$) }\end{array}$ & Commodity & Value (Million US\$) \\
\hline 1 & Oil and gas & $19.018,30$ & Oil and gas & $28.039,60$ & Oil and gas & $41.477,10$ & Oil and gas & $36.977,00$ & Oil and gas & $32.633,20$ \\
\hline 2 & Coal & $13.817,30$ & Coal & $18.499,30$ & Coal & $27.221,80$ & Coal & $26.166,30$ & Coal & $24.501,40$ \\
\hline 3 & Palm oil & $10.367,62$ & Palm oil & $13.468,97$ & Palm oil & $17.261,30$ & Palm oil & $18.845,00$ & Palm oil & $15.839,10$ \\
\hline 4 & Tourism & $6.298,02$ & Processed rubber & $9.314,97$ & Processed rubber & $14.258,20$ & Processed rubber & $10.394,50$ & Tourism & $10.054,10$ \\
\hline 5 & Apparel & $5.735,60$ & Tourism & $7.602,45$ & Tourism & $8.554,40$ & Tourism & $9.120,85$ & Processed rubber & $9.316,60$ \\
\hline 6 & Processed rubber & $4.870,68$ & Apparel & $6.598,11$ & Apparel & $7.801,50$ & Apparel & $7.304,70$ & Apparel & $7.501,00$ \\
\hline 7 & Electric appliance & $4.580,18$ & Electric appliance & $6.337,50$ & Electric appliance & $7.364,30$ & Electric appliance & $6.481,90$ & Electric appliance & $6.418,60$ \\
\hline 8 & Textile & $3.602,78$ & Textile & $4.721,77$ & Textile & $5.563,30$ & Textile & $5.278,10$ & Processed foods & $5.434,80$ \\
\hline 9 & Paper and goods from paper & $3.405,01$ & Paper and goods from paper & $4.241,79$ & Processed foods & $4.802,10$ & Processed foods & $5.135,60$ & Textile & $5.293,60$ \\
\hline 10 & Processed foods & $2.960,73$ & Processed foods & $3.620,86$ & Chemical materials & $4.630,00$ & Paper and goods from paper & $3.972,00$ & Paper and goods from paper & $3.802,60$ \\
\hline 11 & Processed woods & $2.275,32$ & Chemical materials & $3.381,85$ & Paper and goods from paper & $4.214,40$ & Chemical materials & $3.636,30$ & Processed woods & $3.514,50$ \\
\hline 12 & Chemical materials & $2.155,41$ & Processed woods & $2.870,49$ & Processed woods & $3,288,90$ & Processed woods & $3.337,70$ & Chemical materials & $3.501,60$ \\
\hline
\end{tabular}

Source: Kemenpar (2015)

The halal industry was first sounded in 1970 with the provision of food, beverage, and pharmacy products. Halal industry then evolved to the retail banking, investment banking, wealth management, and project financing. In 2000, halal industry tapped the business of travel, hospitality, recreation, medical care, logistic, IT, integrated halal industry parks, certification bodies, and standardization bodies.
The halal or sharia tourism did not grow as fast as the conventional tourism because the former requires several criteria to be included as shariacompliant or halal tourism. The opportunity of this industry is high. The Muslim population in the world is around 1.6 billion people, and $25 \%$ of them are people with a high income. The 56 Muslim countries have the GDP for a total of 6.7 
Jurnal Bisnis dan Manajemen, Volume 19, No. 2, September 2018, p. 122-139

trillion US dollars. This condition indicates the vast opportunity for developing the halal tourism.

The tourism sector is the second most dependable contributor to the state income after oils and gasses. In West Java province alone, the tourism industry is the fourth most significant contributor to the local income or PDRB (gross regional domestic product) after oils and gases, coals, and palm oils. In 2016, the number of tourist coming to West Java was 45 million tourists. A million of this number was the foreign tourists or $2.5 \%$. In 2017 , the number of the foreign tourists grew to be 1.99 million people, but it was still much lower than the domestic tourists. In 2010, the government of West Java targeted five million foreign tourists visiting West Java areas. The government is concerned with the development of sharia tourism. All aspects support the development of this sector, including the increasing number of tourism destination, the number of population, facilities, and infrastructure. The target should be supported by all parties, including by the businesses in the tourism industry, especially the sharia hotels.

Chookaew, Chanin, Charatarawat, Sriprasert, \& Nimpaya (2015) stated that there eight standard factors which can be used to measure the sharia tourism regarding administration and management. The first factor is the services provided to the tourists must be shariacompliant. Secondly, the tourist guides and staff should uphold the Islamic principles. Thirdly, all activities must not against Islamic laws. Fourthly, the buildings must be in accordance with Islamic laws. Fifthly, the restaurants must follow the international halal standard. Sixthly, the transportation must be safe and secured. Seventhly, the praying rooms must be provided, and the last, the traveling activities must not against Islamic principles.

To fulfill those criteria, the aspects of human resources are pivotal in achieving the optimum results. Those human resources must be able to understand and implement the Islamic values in their activities. Also, the roles of Islamic leaders and the implementation of Islamic values are needed as these may affect the employee productivity.

From the observation of some sharia hotels in Bandung, it was found that the leadership and Islamic values were not entirely implemented (kaffah) yet. One of the indications could be seen from the dress of the employees which was not in accordance with Islamic teachings. Thus, this research aims to describe the Islamic leadership, internalization of work ethic, and employee productivity of the sharia hotels. Besides, this research tries to explore the effect of Islamic leadership and Islamic work ethic on the employee productivity in the sharia hotels in Bandung, the largest city of West Java Province.

\section{LITERATURE REVIEW Islamic Leadership}

According to the aspect of sharia or 'aqli (thought), leadership is something that must exist. According to sharia aspect, it is stated in the Holy Quran regarding the prayer of the salvaged people that 
Jurnal Bisnis dan Manajemen, Volume 19, No. 2, September 2018, p. 122-139

"....and make us an example for the righteous" (QS

Al-Furqan: 74). Allah Almighty also says in the Quran "O you who have believed, obey Allah and obey the Messenger and those in authority among you”" (QS An-Nisaa': 59). The prophet Muhammad also says in a well-known hadith that "Every single of you is a leader and you will be asked for his leadership." Another hadith also indicates the importance of selecting a leader on a journey of three persons. In an aqli aspect, it is understandable that an institution without a leader will let that institution broken or destroyed (Hakim, 2007).

Hakim (2007) also emphasized that several characteristics of Muslim leader are i) having a sufficient knowledge and capability for controlling his firms, ii) having specialty compared to others, iii) understanding the language and habits of this subordinates, iv) having charisma and power in front of people, v) upholding the virtues and having self-control, vi) showing love and compassion to his subordinates resulting sympathy from others, vii) loving the forgiving action between the leader and the followers, viii) performing discussion with his subordinates and asking their opinions, ix) clearing every business problem and submitting it (being tawakal) to Allah, $\mathrm{x}$ ) building the awareness for muraqabah (being watched by Allah), xi) providing takaaful ijtima'I (social assistance) to his subordinates, reducing gap and inequality among them, xii) having a strong influence and power to command, prevent the wrong actions, fix the problem, and invite to the right things, and xiii) preventing the actions of destructing any properties and environment.
A Muslim must not; break the relationship with ahli dzimmi (non-Muslim) underestimate and make the joy of the weak people, compete in a dirty way, cheat the business partner, and sell unlawful goods or services. Allah threats the unjust leaders as stated in the Quran. The leaders must listen to the advice. They must not be arrogant because the advice of a good person is so meaningful.

The leadership in Islam has various definitions. Imamah means going forward, taking an example and leading. Khilafah means resulting in the successor or Khalifa. Ulul Amri means people who have business and managing. Wilayah means governing, mastering, loving, and helping, while Ri'ayah means herding, maintaining, and protecting. Imamah implies that a leader or Imam should be the example for his subordinates and he should have clear goals or orientations regarding the direction of his organization.

Hakim (2007) further explained that Islamic Leadership is a leadership practicing the values of Islam, either the leader is a Muslim or not. In reality, there are Muslim leaders but do not practice the norms or principle of Islam, such as Amanah (trusted), 'Adil (just), syura (making consensus in decision making) and others. Meanwhile, we may also encounter the nonMuslim leaders practicing the values of Islam such as punctuality, just and others. The ideal Islamic leadership is the leadership, system, and managerial mechanism in an organization where the leader and the followers are both the obey people and the ones implementing the teachings of Islam. 
Jurnal Bisnis dan Manajemen, Volume 19, No. 2, September 2018, p. 122-139

In the perspective of Islam, leadership is actions of directing, guiding, and showing the ways blessed by Allah. Those actions aim to develop the capabilities of both the leaders and followers in the world and hereafter. The excellent characteristics of the Prophet Muhammad are as follows (Nawawi \& Hadari, 2012):

a. Shiddiq (honest). The person upholding this characteristic has honesty and integrity in his saying and action in accordance with Islam. The honesty is shown in the behavioral, working, and financial aspect.

b. Amanah. This means fully responsible, trusted and shows a good performance in every task. The person upholding this characteristic shows openness, honesty, excellent service, and Ihsan (doing the best thing in every occasion to perform maximum service to the society). This characteristic prevents collusion, corruption, manipulation and will support full trust from the followers and others. Thus, the programs proposed will be fully supported.

c. Fathonah. This means the leader must be intelligent or capable of solving any problem, finding solution, and owning broad knowledge. The smart leader shall perform any initiative precisely, accurately, and quickly when encountering any problem. As Islam was revealed to all humanity and is a blessing to the universe, only the smart leaders can provide guidance, advice, guidelines, opinions, and viewpoints for the people.

d. Tabligh. This characteristic is in line with Amanah, meaning the leader can invite and be an example to his subordinates. He can mingle with the coworkers, has the skills in negotiating, and is transparent or open to conduct the organizational management. The programs are delivered wisely, patiently, argumentatively, and persuasively, resulting in a stronger and more solid relationship. This characteristic is indicated in performing the service to the society, dressing, getting used to praying in Jemaah (together), praying in the beginning and end of the work, and so on.

Thus, this research uses the following indicators as the variable of Islamic leadership; (i) Shiddiq / honest: (ii) amanah (trusted); (iii) Fathonah (intelligent); (iv) 'adil (just); (v) syura (making consensus in decision making); (vi) Tabligh (capable in doing the mandate) and; (vii) disciplined.

\section{Internalization of Islamic Work Ethic}

The term internalization is a process happening in an educational activity. Within the internalization, it is not only the knowledge transformation that happens from the educator to the students but also the actualization and full comprehension of the values. Those values then become the personality and life principle of the students. Thus, internalization is an effort to fully comprehend and dig the values deeply so those values will be rooted in every human being. 
Jurnal Bisnis dan Manajemen, Volume 19, No. 2, September 2018, p. 122-139

Ethic is defined as the activity in adhering the moral teachings for the concrete problem (Ahmad \& Owoyemi, 2012). Ethic is a part of philosophy where experts have a different opinion on it (Ya'qub, 1983). But, ethic can be concluded as the science of studying the values and morality of the individual, represented by the behavior in valuing an action which is good or bad.

Work ethic is a belief that hard work and earnest have an excellent benefit, attached capability, and virtues strengthening the characteristic (Business Dictionary, 2018). Work ethic will prioritize the work and put it in the center of the life. Islamic work ethic has a positive and significant relationship with the individualism where the young managers tend to have higher level of individualistic (El-Kot \& Burke, 2014).

Islamic ethic teaches and guides humanity to the good behavior and prevents them from the evil doers. Islamic ethic is universal and can be accepted by humanity, anywhere and anytime (Ya'qub, 1983).

Islamic work ethic is compatible with any era and can be implemented by any groups of people. Whereas, other theories of ethic often change and only follow a particular situation and condition of the people.

Islam has three essential elements which are the inseparable series, namely aqeedah, sharia, and akhlak. Aqeedah means obedience and faith of human in Allah SWT. Sharia means the actions of human both in eebadat and muamalat. Eebadat is vertical worship or relationship between a worshiper and Allah, while muamalat is the excellent relationship among people. The third element, akhlak, represents the ethic and actions related to the behavior and personality of the humanity.

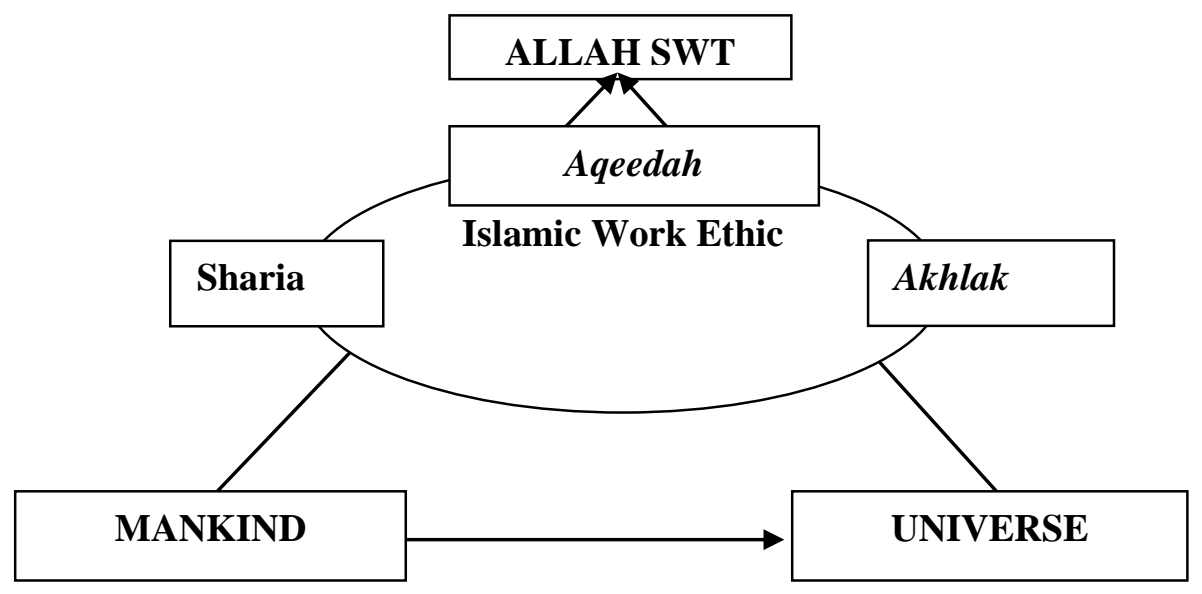

Figure 1 The framework of Islamic Work Ethic

Figure 1 shows the Islamic work ethic implemented by the Muslim employees which is the manifestation of the three correlated relationships, namely, the relationship between humanity and Allah, the relationship between MODEL FOR IMPROVING THE EMPLOYEE PRODUCTIVITY THROUGH ISLAMIC LEADERSHIP AND INTERNALIZATION OF ISLAMIC WORK ETHIC IN SHARIA TOURISM (STUDY ON SHARIA HOTELS IN BANDUNG) humanity, and the relationship between humanity and universe. Any employees working for sharia hotels must uphold the principles of aqeedah, sharia and akhlak. 
Jurnal Bisnis dan Manajemen, Volume 19, No. 2, September 2018, p. 122-139

Islam has two definitions for working, namely, firstly working as the general meaning which is the efforts of human in searching for material or non-material things, and physical or intellectual things related to the world and hereafter. Secondly, working refers to the narrow meaning, namely the efforts for fulfilling any needs such as goods, clothes, and housings which are the basic need of people. The fulfillment of these needs must be done as an eebadat.

Narrated Al-Baihaqi in 'Syu'bul Iman,' there are four working principles taught by the Prophet Muhammad. The believer should own those four principles if he or she wants to see Allah in the paradise, namely 1) Thalaba ad-dunya halalan (working only in a halal job), Ta'affufan an al-mas'alah (working to protect ourselves from begging, being the burden of others), Sa'yan ala iyalihi (working to fulfil family needs) and Ta'aththufan ala jarihi (working to provide help to the neighbors).

Islam does not like those who are lazy and dependent on others. Working is not just urged as it gives benefit to other people, but it is also a noble thing if we conduct the activities beneficial for other creatures.

Islamic work ethic is the serious effort by using the total ability, thinking, and remembrance of Allah to actualize ourselves as the servants of Allah in conquering the world and positioning ourselves as the part of the best society (Tasmara, 2002).
Islamic work ethic emphasizes that working is needed for the goodness of personal life in every individual human being (Rizk, 2008). This concept is based on the Holy Quran, and the hadith of the Prophet Muhammad saying working in a halal way will erase the small sins (Rokhman, 2010).

In performing the job or task, the employees prioritize positive ways of behaving and acting with other employees and superordinates. This is in line with the Holy Quran and hadith of the Prophet. Some of the underlying elements of Islamic work ethic are sincerity, honesty, trustfulness, and fraternity (ukhuwah).

Sincerity means that everything is done for the sake of pleasing Allah Almighty, not just for fulfilling personal pleasures. The sincere intention will determine the acceptance of Allah on the good deeds (Al- Ghazali, 2005).

The prophet Muhammad says: "You will never spend anything seeking the Face of Allah thereby, but you will be rewarded for it, even (the food) that you put in your wife's mouth" (narrated Bukhari and Muslim).

The values of sincerity are shown in the following indicators; seeking only Allah's please in every action, doing something full heartedly and with full of awareness, being diligent and not inferior for what is being done, doing something not because of the force of others, and accepting advice, suggestions, and critics. 
Jurnal Bisnis dan Manajemen, Volume 19, No. 2, September 2018, p. 122-139

Honesty is reflected in the harmony of the heart, saying and action. What has been intended by the heart, spoken verbally and portrayed in the act of activity is what is carried out in the view of sharia. Honesty has a comprehensive meaning including the feeling of humans who want to carry out any form of kindness and realize that they will account for it in the afterlife before Allah.

The moral foundation of Islamic work is carrying out the fundamental values of religion as a foundation for building and starting work. Some matters are related to the moral foundation of work. They are 1) being self-monitored which means that somebody realizes that everything he does cannot be separated from the requests and visions of Allah SWT, 2) honesty which is the conscience that will guarantee spiritual happiness because the truth of work and accuracy of work will result in trust from other people, 3) trusteeship which is trust given to others, and 4) Taqwa which is an attitude of mindfulness possessed by humans to protect themselves against the wrath of Allah by not persecuting themselves or others.

According to Ali (1992), there are ten dimensions or indicators of Islamic work ethic, namely, diligence, dedication, good deeds, just, mercy, productivity, achievement, social relationship, hard work, and social orientation.

Meanwhile, Ali \& Al-Owaihan (2008) employed six dimensions, namely, effort, dedication, responsibility, social relationship, and creativity. Manan, Kamaluddin, \& Puteh Salin,
(2013) also measured the Islamic work ethic, but they only used four dimensions which are specific in the banking sector, namely, effort, teamwork, honesty, and responsibility. The precise description of the indicators of Islamic work ethic is shown in table 2 . 
Table 2 Islamic Work Ethic

\begin{tabular}{|c|c|c|c|}
\hline No & Authors & Definition & Dimensions \\
\hline 1. & Ali (1992) & $\begin{array}{l}\text { Islamic work ethic can form or } \\
\text { influence the involvement and } \\
\text { participation of employees in the } \\
\text { workplace }\end{array}$ & $\begin{array}{l}\text { 1. } \text { diligence, } \\
\text { 2. dedication, } \\
\text { 3. good deeds, } \\
\text { 4. just, } \\
\text { 5. mercy, } \\
\text { 6. productivity, } \\
\text { 7. achievement, } \\
\text { 8. social relationship, } \\
\text { 9. hard work, and } \\
\text { 10. } \text { social orientation }\end{array}$ \\
\hline 3. & $\begin{array}{l}\text { Ali \& Al-Owaihan } \\
(2008)\end{array}$ & $\begin{array}{l}\text { Islamic work ethic is formed based on } \\
\text { the noble goals of somebody in his } \\
\text { workplace }\end{array}$ & $\begin{array}{l}\text { 1. effort } \\
\text { 2. Dedication } \\
\text { 3. Cooperation } \\
\text { 4. Responsibility } \\
\text { 5. Social relationship } \\
\text { 6. Creativity }\end{array}$ \\
\hline 4. & $\begin{array}{l}\text { Manan, } \\
\text { Kamaluddin, \& } \\
\text { Puteh Salin, } \\
\text { (2013) }\end{array}$ & $\begin{array}{l}\text { Islamic work ethic is the concept } \\
\text { where working is a worship related to } \\
\text { the economic aspect }\end{array}$ & $\begin{array}{l}\text { 1. Effort } \\
\text { 2. Teamwork } \\
\text { 3. Honesty } \\
\text { 4. Responsibility }\end{array}$ \\
\hline
\end{tabular}

Source: Ali \& Owaihan (2008); Manan, Kamaluddin, \& Puteh Salin, (2013)

Thus, this research uses the following indicators in measuring the Islamic work ethic: i) honesty, ii) hard work, iii) dedication, iv) responsibility, v) good social relationship, vi) good teamwork/cooperativeness, vii) creativity, and viii) mercy.

\section{Employee Productivity}

In general, productivity is the comparison between output and input. Sedarmayanti (2009) confirmed that productivity is the positive contribution of somebody to his environment where he is working for. The constructive, imaginative, and creative actions will affect the productivity of an organization. Some scholars have different views on the dimension of productivity. Simanjuntak
(1985) used quality and working environment as employee welfare dimensions of productivity. Meanwhile, Sedarmayanti (2009) only used effectiveness and efficiency. Productivity has two dimensions. The first dimension is effectiveness which directs to the maximum performance (target to be achieved related to the quality, quantity and time). The second dimension of productivity relates to the effort between the input and the realization of the use, or how a job is being done.

Thus, the research paradigm is portrayed in figure 2 . 


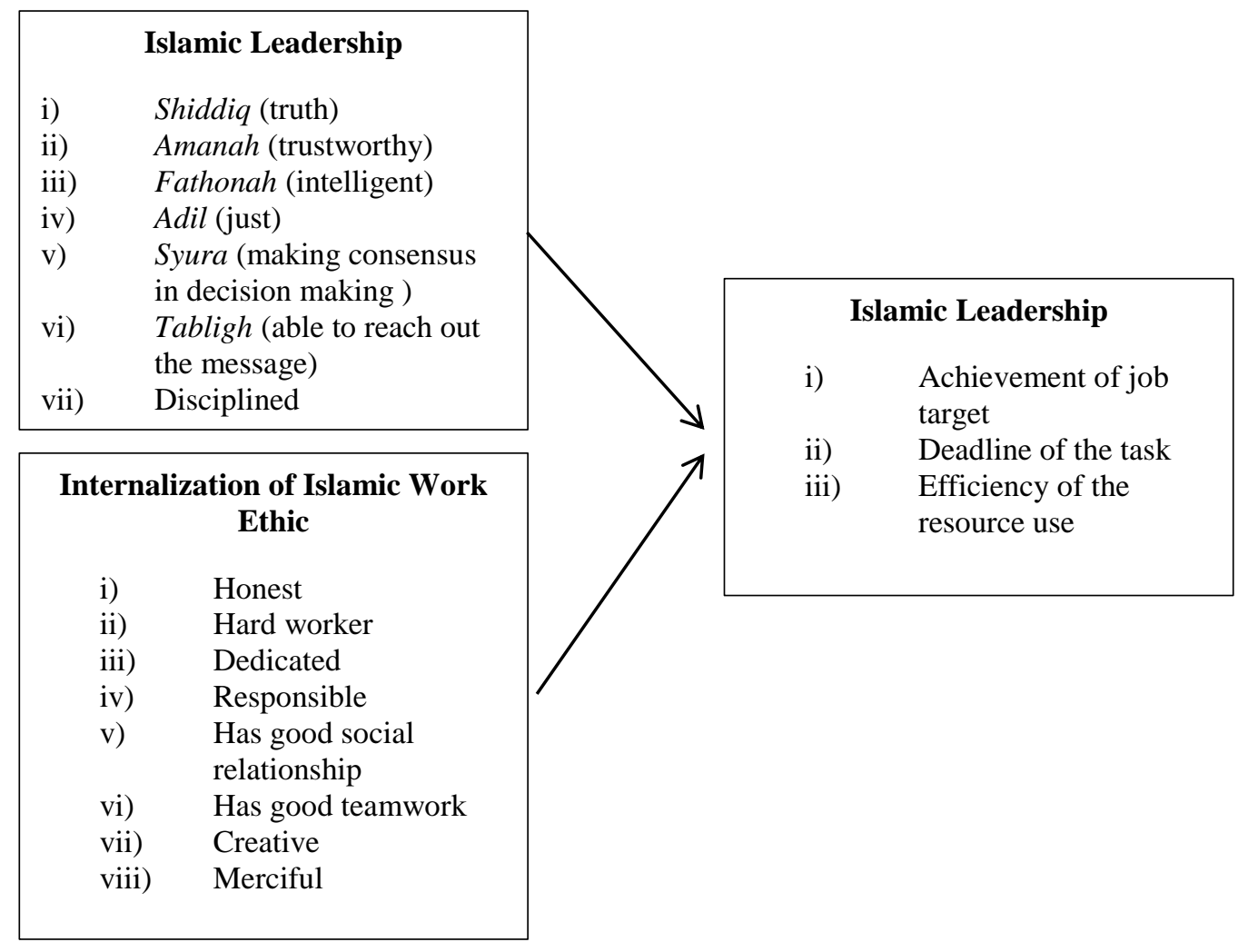

Figure 2 Research Paradigm

Source: processed data (2018)

\section{METHODS}

The unit of analysis and observation in this research is the employees of the sharia hotels in Bandung. There are six sharia hotels in Bandung, namely Cinnamon Boutique Syariah, Orange Home Syariah, Ruby Hotel, Narapati Syariah, Noor Hotel, and Rumah Tawa. Of these six hotels, three of them are categorized as three-star hotels, and the rest is the budget hotels. The selected hotels are Cinnamon Boutique Syariah, Orange Home Syariah, and Rumah Tawa. Of this three hotels, 60 employees were taken as the respondents, comprising 30 employees of Cinnamon Boutique Syariah, 20 employees of Orange Home Syariah and ten employees of Rumah Tawa hotel.

The data were collected using questionnaires distributed to the employees, and to the managers for clarification purpose. The data analysis and processing were performed using PLS (Partial Least Square) to explore the effect of the variables and the degree of the manifest variable in influencing the latent variables.

The test for validity was performed to see the level of validity of each question and indicator used as the measurement. The test for reliability was conducted to measure the level of reliability of the variable. The results of these tests showed that the three variables in this study are valid and reliable. 
Jurnal Bisnis dan Manajemen, Volume 19, No. 2, September 2018, p. 122-139

RESULTS AND DISCUSSION

Islamic Leadership, Internalization of Islamic Work Ethic, and Productivity of Sharia Hotel Employees in Bandung

Islamic Leadership

Islamic leadership, measured by its indicators, is in a strong category, ranging from 3.63 to 4.30 . The highest score is the variable of discipline, meaning the leaders of sharia hotels in our research have the high discipline. Discipline is indeed needed as it will help in making a decision, performing coordination, formulating strategies, and so on. Nonetheless, this aspect must also be accompanied by other aspects, namely, intelligence, trust, trustworthy, and tabligh.

The lowest score is the variable of just, meaning that the leaders of sharia hotels in Bandung are considered less fair by the employees. The aspect is in a strong category, but compared to other aspects, the score is the lowest. The score of the variables is shown in table 3.

Table 3 Islamic Leadership

\begin{tabular}{|c|c|c|c|c|c|c|c|c|c|c|}
\hline \multirow{2}{*}{ No. } & \multirow{2}{*}{ Indicator } & & \multicolumn{5}{|c|}{ Response of Employees } & \multirow{2}{*}{ Total } & \multirow{2}{*}{$\begin{array}{l}\text { Weighted } \\
\text { Average }\end{array}$} & \multirow{2}{*}{ Category } \\
\hline & & & 5 & 4 & 3 & 2 & 1 & & & \\
\hline 1 & Shiddiq (truth) & $F$ & 8 & 33 & 16 & 3 & 0 & 60 & \multirow{3}{*}{3.76} & \multirow{3}{*}{ Strong } \\
\hline \multirow{4}{*}{2} & \multirow{4}{*}{ Amanah (trustworthy) } & $\%$ & 13.33 & 55 & 26.67 & 5 & 0 & 100 & & \\
\hline & & Weight & 40 & 132 & 48 & 6 & 0 & 226 & & \\
\hline & & $\mathrm{F}$ & 11 & 31 & 12 & 5 & 1 & 60 & \multirow{2}{*}{3.76} & \multirow{2}{*}{ Strong } \\
\hline & & $\%$ & 18.33 & 51.67 & 20 & 8.33 & 1,7 & 100 & & \\
\hline \multirow{4}{*}{3} & \multirow{3}{*}{ Fathonah (intelligent) } & Weight & 55 & 124 & 36 & 10 & 1 & 226 & \multirow{4}{*}{4.1} & \multirow{4}{*}{ Strong } \\
\hline & & $\mathrm{F}$ & 17 & 34 & 7 & 2 & 0 & 60 & & \\
\hline & & $\%$ & 28.33 & 56.67 & 11.67 & 3.33 & 0 & 100 & & \\
\hline & \multirow{4}{*}{ Adil (just) } & Weight & 85 & 136 & 21 & 4 & 0 & 246 & & \\
\hline & & $\mathrm{F}$ & 8 & 31 & 15 & 3 & 3 & 60 & \multirow{3}{*}{3.63} & \multirow{3}{*}{ Strong } \\
\hline \multirow[t]{3}{*}{4} & & $\%$ & 13.33 & 51.67 & 25 & 5 & 5 & 100 & & \\
\hline & & Weight & 40 & 124 & 45 & 6 & 3 & 218 & & \\
\hline & \multirow{3}{*}{$\begin{array}{l}\text { Syura (making consensus } \\
\text { in decision making) }\end{array}$} & $\mathrm{F}$ & 12 & 33 & 11 & 4 & 0 & 60 & \multirow{3}{*}{3.88} & \multirow{3}{*}{ Strong } \\
\hline \multirow[t]{2}{*}{5} & & $\%$ & 20 & 55 & 18.33 & 6.67 & 0 & 100 & & \\
\hline & & Weight & 60 & 132 & 33 & 8 & 0 & 233 & & \\
\hline \multirow{3}{*}{6} & \multirow{3}{*}{$\begin{array}{l}\text { Tabligh (able to reach out } \\
\text { the message) }\end{array}$} & $\mathrm{F}$ & 8 & 32 & 14 & 4 & 2 & 60 & \multirow{3}{*}{3.66} & \multirow{3}{*}{ Strong } \\
\hline & & $\%$ & 13.33 & 53.33 & 23.33 & 6.67 & 3.33 & 100 & & \\
\hline & & Weight & 40 & 128 & 42 & 8 & 2 & 220 & & \\
\hline & \multirow[t]{4}{*}{ Discipline } & F & 21 & 34 & 5 & 1 & 0 & 60 & \multirow{3}{*}{4.30} & \multirow{3}{*}{ Very Strong } \\
\hline \multirow[t]{3}{*}{7} & & $\%$ & & & & & & 100 & & \\
\hline & & Weight & 105 & 136 & 15 & 2 & 0 & 258 & & \\
\hline & & & Avera & & & & & & 3.87 & Strong \\
\hline
\end{tabular}

Source: Processed data (2018)

Internalization of Islamic Work Ethic

Internalization, measured by its indicators, is overall in the strong category. This means the employees of sharia hotels in Bandung are generally able to implement the values of Islamic work ethic. This implies that the employees uphold 
Jurnal Bisnis dan Manajemen, Volume 19, No. 2, September 2018, p. 122-139

the values of honesty, hard work, dedication, responsibility, creativity, and mercy.

Of the eight indicators reflecting the internalization of Islamic work ethic, the lowest score is creativity. This means that generally, the employees of sharia hotels in Bandung are less creative. Nonetheless, this score is in the high score, but compared to other variables, the score is the lowest. So, this aspect needs to be paid attention. The score of all indicators is shown in table 4.

\section{Table 4 Internalization of Islamic Work Ethic}

\begin{tabular}{|c|c|c|c|c|c|c|c|c|c|c|}
\hline \multirow[t]{2}{*}{ No. } & \multirow[t]{2}{*}{ Indicator } & & \multicolumn{5}{|c|}{ Response of Employees } & \multirow[t]{2}{*}{ Total } & \multirow{2}{*}{$\begin{array}{c}\text { Weighted } \\
\text { Average }\end{array}$} & \multirow[t]{2}{*}{ Category } \\
\hline & & & 5 & 4 & 3 & 2 & 1 & & & \\
\hline \multirow[t]{3}{*}{1} & Honesty & $\mathrm{F}$ & 8 & 23 & 26 & 2 & 1 & 60 & \multirow{2}{*}{3.58} & \multirow[t]{2}{*}{ Strong } \\
\hline & & $\%$ & 13.33 & 38.33 & 43.33 & 3.33 & 0.17 & 100 & & \\
\hline & & Weight & 40 & 92 & 78 & 4 & 1 & 215 & \multirow{4}{*}{3.48} & \multirow{4}{*}{ Strong } \\
\hline \multirow{3}{*}{2} & Hard work & $\mathrm{F}$ & 6 & 22 & 27 & 5 & 0 & 60 & & \\
\hline & & $\%$ & 10 & 36.67 & 45 & 8.33 & 0.17 & 100 & & \\
\hline & & Weight & 30 & 88 & 81 & 10 & 0 & 209 & & \\
\hline \multirow[t]{3}{*}{3} & Dedication & F & 6 & 24 & 24 & 5 & 1 & 60 & \multirow[b]{2}{*}{3.48} & \multirow[b]{2}{*}{ Strong } \\
\hline & & $\%$ & 10 & 40 & 40 & 8.33 & 1.67 & 100 & & \\
\hline & & Weight & 30 & 96 & 72 & 8 & 3 & 209 & \multirow{4}{*}{3.53} & \multirow{4}{*}{ Strong } \\
\hline \multirow[t]{3}{*}{4} & Responsibility & $\mathrm{F}$ & 8 & 22 & 25 & 4 & 1 & 60 & & \\
\hline & & $\%$ & 13.33 & 36.67 & 41.67 & 6.67 & 1.67 & 100 & & \\
\hline & & Weight & 40 & 88 & 75 & 8 & 1 & 212 & & \\
\hline \multirow[t]{3}{*}{5} & Has a good social & $\mathrm{F}$ & 15 & 32 & 11 & 2 & 0 & 60 & \multirow[t]{3}{*}{4.00} & \multirow[t]{3}{*}{ Strong } \\
\hline & relationship & $\%$ & 25 & 53.33 & 18.33 & 3.33 & 1.67 & 100 & & \\
\hline & & Weight & 75 & 128 & 33 & 4 & 0 & 240 & & \\
\hline \multirow[t]{3}{*}{6} & Has a good teamwork & $\mathrm{F}$ & 14 & 31 & 13 & 2 & 0 & 60 & \multirow[t]{3}{*}{3.95} & \multirow[t]{3}{*}{ Strong } \\
\hline & & $\%$ & 23.33 & 51.67 & 21.67 & 3.33 & 0 & 100 & & \\
\hline & & Weight & 70 & 124 & 39 & 4 & 0 & 237 & & \\
\hline \multirow[t]{3}{*}{7} & Creative & $\mathrm{F}$ & 5 & 16 & 27 & 9 & 3 & 60 & \multirow[t]{3}{*}{3.18} & \multirow[t]{3}{*}{ Fair } \\
\hline & & $\%$ & 8.33 & 26.67 & 45 & 15 & 5 & 100 & & \\
\hline & & Weight & 25 & 64 & 81 & 18 & 3 & 191 & & \\
\hline \multirow[t]{4}{*}{8} & Merciful & F & 8 & 20 & 25 & 7 & 0 & 60 & \multirow[t]{3}{*}{3.48} & \multirow[t]{3}{*}{ Strong } \\
\hline & & $\%$ & 13.33 & 33.33 & 41.67 & 11.67 & 0 & 100 & & \\
\hline & & Weight & 40 & 80 & 75 & 14 & 0 & 209 & & \\
\hline & & & Aver & & & & & & 3.585 & Strong \\
\hline
\end{tabular}

Source: Processed data (2018)

\section{Employee Productivity}

As an effect of the strong Islamic leadership and internalization of Islamic work ethic, the productivity of sharia hotel employees in Bandung is overall in the strong category. However, there are three aspects that need to be the concern, namely, 
Jurnal Bisnis dan Manajemen, Volume 19, No. 2, September 2018, p. 122-139

low supervision, lack of honesty, and lack of responsibility of the employees.

The achievement of the target, in general, is always days behind schedule. This means, even though the task is always accomplished, there is always a delay in its accomplishment. Thus, the hotels should conduct counseling regarding the importance of working discipline. The overall score of the indicators is shown in table 5.

Table 5 Employee Productivity

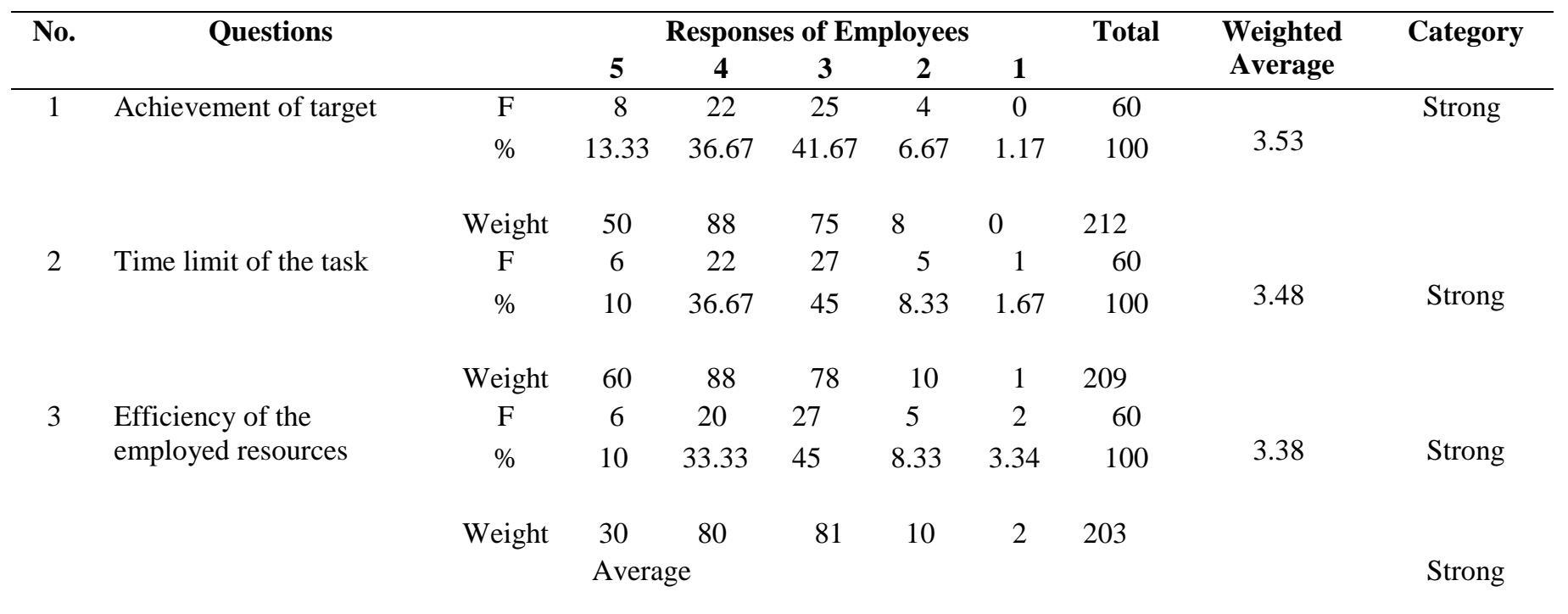

Source: Processed data (2018)

Effect of Islamic Leadership and Internalization of Islamic Work Ethic on Productivity of Sharia Hotel Employees in Bandung

Correlation among Islamic work ethic, internalization of Islamic work ethic, and productivity of sharia hotel employees in Bandung To measure the effect of the variables, it is important to first measure to correlation among them. The coefficient correlation calculation uses
Pearson Product Moment. The measurement was conducted to know the strength of the relationship between the independent variables in this research. For the calculation, SPPS software was utilized with results shown in table 6.

Table 6 Correlation Coefficient between Independent Variables

\begin{tabular}{|c|c|c|c|c|}
\hline Model & & & Islamic_Work_Ethic & Islamic_Leadership \\
\hline \multirow{4}{*}{1} & \multirow{2}{*}{ Correlations } & Islamic_Work_Ethic & 1.000 & -.955 \\
\hline & & Islamic_Leadership & -.955 & 1.000 \\
\hline & \multirow{2}{*}{ Covariances } & Islamic_Work_Ethic & .001 & -.001 \\
\hline & & Islamic_Leadership & -.001 & .001 \\
\hline
\end{tabular}

Source: Processed data using SPSS software (2018)

The correlation coefficient among the variables in this study is shown in the table 7. 
Jurnal Bisnis dan Manajemen, Volume 19, No. 2, September 2018, p. 122-139

Table 7 Correlation Coefficient among Variables

\begin{tabular}{llrrr}
\hline & & $\begin{array}{c}\text { Employee_Productivity } \\
(\mathbf{Y})\end{array}$ & $\begin{array}{c}\text { Islamic_Leadership } \\
\text { (X1) }\end{array}$ & $\begin{array}{c}\text { Islamic_Work_Ethic } \\
\text { (X2) }\end{array}$ \\
\hline \multirow{3}{*}{ Pearson Correlation } & Employee_Productivity & 1.000 & .918 & .982 \\
& Islamic_Leadership & .918 & 1.000 & .955 \\
& Islamic_Work_Ethic & .982 & .955 & 1.000 \\
Sig. (1-tailed) & Employee_Productivity & .000 & .000 \\
& Islamic_Leadership & .000 &. & .000 \\
& Islamic_Work_Ethic & .000 & .000 & .60 \\
N & Employee_Productivity & 60 & 60 & 60 \\
& Islamic_Leadership & 60 & 60 & 60 \\
\hline
\end{tabular}

Source: Processed data using SPSS software (2018)

Based on the table above, it is shown that the correlation between the independent variables is positive, meaning that the higher the change of a variable, the higher the other variable becomes. The more detailed description of the variable is shown in the figure 3:

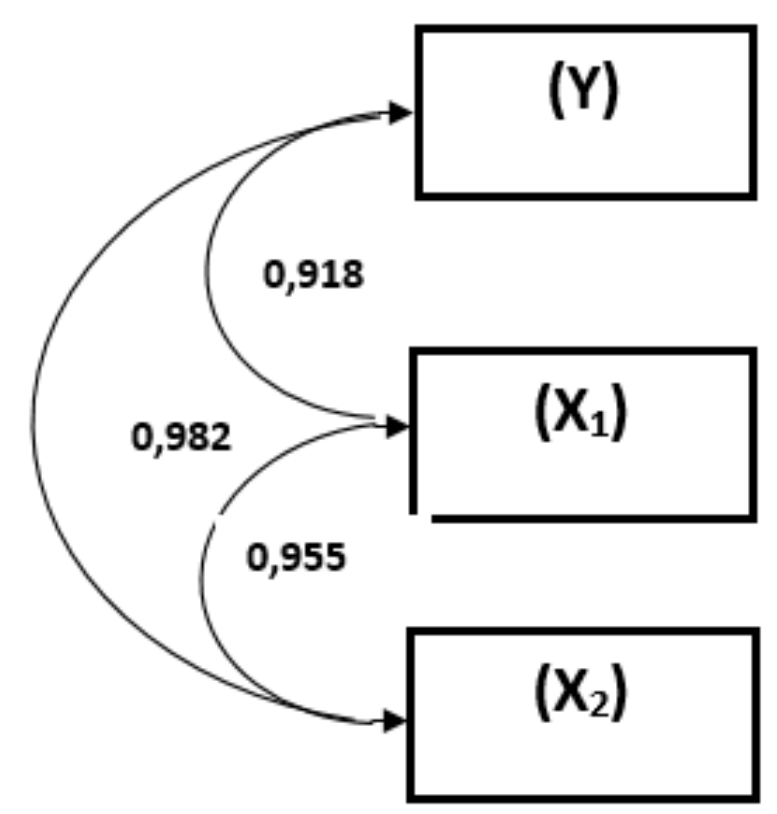

Figure 3 The relationship between the Islamic Leadership, Internalization of Islamic Work Ethic, and Employee Productivity 
Jurnal Bisnis dan Manajemen, Volume 19, No. 2, September 2018, p. 122-139

The tightness criteria of the variables in this research are shown in table 8.

\section{Table 8 Interpretation Criteria of the} Relationship between the Variables

\begin{tabular}{cc}
\hline $\begin{array}{c}\text { Coefficient } \\
\text { Correlation }\end{array}$ & Relationship Criteria \\
\hline $0.00-0.199$ & Very low \\
$0.20-0.399$ & Low \\
$0.40-0.599$ & Fair \\
$0.60-0.799$ & Strong \\
$0.80-1.000$ & Very strong \\
\hline
\end{tabular}

Source: Sugiyono (2009)

Based on the table above, as the relationship between Islamic Leadership $\left(\mathrm{X}_{1}\right)$ and Islamic Ethic $\left(\mathrm{X}_{2}\right)$ has the value of 0.955 , it can be stated that the correlation between these two variables is strong and positive. The correlation is significant because the significance value is 0.000 , lower than 0.01 . The same thing happens to the relationship between Islamic Leadership $\left(\mathrm{X}_{1}\right)$ and Employee Productivity (Y) which is also strong and positive, indicated by the value of 0.918 . The correlation between $\mathrm{X}_{1}$ and $\mathrm{Y}$ is significant because the significance value is 0.000 , lower than 0.01 . Also, the correlation between Islamic Ethic $\left(\mathrm{X}_{2}\right)$ and Employee Productivity (Y) is strong and positive, shown by the value of 0.982 . The correlation between $\mathrm{X}_{2}$ and $\mathrm{Y}$ is also significant because the significance value is 0.000 , lower than 0.01 .

\section{Effect of Islamic Leadership on Employee Productivity}

Based on the calculation results using SPSS software, the results obtained shown in table 9.

Table 9 Coefficients of Research Variables

\begin{tabular}{|c|c|c|c|c|c|c|c|c|c|c|c|c|}
\hline \multirow[t]{2}{*}{ Model } & \multicolumn{2}{|c|}{$\begin{array}{l}\text { Unstandardized } \\
\text { Coefficients }\end{array}$} & \multirow{2}{*}{$\begin{array}{c}\text { Standardized } \\
\text { Coefficients } \\
\text { Beta }\end{array}$} & \multirow[t]{2}{*}{ t } & \multirow[t]{2}{*}{ Sig. } & \multicolumn{2}{|c|}{$\begin{array}{c}95.0 \% \\
\text { Confidence } \\
\text { Interval for B }\end{array}$} & \multirow[b]{2}{*}{$\begin{array}{l}\text { Zero- } \\
\text { order }\end{array}$} & \multicolumn{2}{|c|}{ Correlations } & \multicolumn{2}{|c|}{$\begin{array}{l}\text { Collinearity } \\
\text { Statistics }\end{array}$} \\
\hline & B & $\begin{array}{l}\text { Std. } \\
\text { Error }\end{array}$ & & & & $\begin{array}{l}\text { Lower } \\
\text { Boun } \\
\text { d }\end{array}$ & $\begin{array}{l}\text { Upper } \\
\text { Bound }\end{array}$ & & Partial & Part & $\begin{array}{c}\text { Toleran } \\
\text { ce }\end{array}$ & VIF \\
\hline (Constant) & -.302 & .310 & & -.976 & .333 & -.923 & .318 & & & & & \\
\hline $\begin{array}{l}\text { Islamic_Leade } \\
\text { rship }\end{array}$ & -.109 & .037 & -.233 & -2.932 & .005 & -.184 & -.035 & .918 & -.362 & -.069 & .087 & 11.461 \\
\hline $\begin{array}{l}\text { Islamic_Work } \\
\text { Ethic }\end{array}$ & .476 & .031 & 1.204 & 15.169 & .000 & .413 & .539 & .982 & .895 & .356 & .087 & 11.461 \\
\hline
\end{tabular}

From table 9, the regression formula can be formed as follows:

$$
Y=-0,302-0,109 X_{1}+0,476 X_{2}
$$

The constant value of -0.302 indicates that if there is no the variable of Islamic Leadership $\left(\mathrm{X}_{1}\right)$ and Islamic Work Ethic $\left(\mathrm{X}_{2}\right)$, the Employee Performance (Y) would be -0.302 . The regression coefficient of -0.109 specifies that a one-point increase in the Islamic Leadership variable will decrease the $\mathrm{Y}$ variable by 0.109 . The regression coefficient of 0.476 means that a one-point increase in the Islamic Work Ethic will increase the $\mathrm{Y}$ variable by 0.476 .

The t-test was conducted to know the significance of the constant value and dependent 
Jurnal Bisnis dan Manajemen, Volume 19, No. 2, September 2018, p. 122-139

variable (Employee Performance). The first hypothesis tested partially is as follows:

$\mathrm{H}_{0}$ : Islamic Leadership does not significantly affect the Employee Productivity

$\mathrm{H}_{\mathrm{a}}$ : Islamic Leadership significantly affects the Employee Productivity

According to the table above, the significance (sig.) value (0.005) is smaller than 0.05 . Thus $\mathrm{H}_{0}$ is rejected which means the regression coefficient is significant. So, it can be said that Islamic Leadership significantly affects the Employee Productivity.

Effect of Internalization of Islamic Work Ethic on Employee Productivity

The second hypothesis tested partially is as follows:
$\mathrm{H}_{0}$ : Islamic Work Ethic does not significantly affect Employee Productivity

$\mathrm{H}_{\mathrm{a}}$ : Islamic Work Ethic significantly affects Employee Productivity

According to the table above, the significance (sig.) value (0.000) is smaller than 0.05 . Thus $\mathrm{H}_{0}$ is rejected which means the regression coefficient is significant. So, it can be said that Islamic Work Ethic affects the Employee Productivity.

Effect of Islamic Leadership and Internalization of Islamic Work Ethic on Employee Productivity

The calculation results using SPSS software are shown in table 10.

Table 10 Simultaneous Effect of X1 and X2 on Y using ANOVA

\begin{tabular}{ccrrrrr}
\hline \multicolumn{10}{c}{ ANOVA $^{\mathbf{a}}$} \\
\hline \multicolumn{1}{c}{ Model } & Sum of Squares & df & Mean Square & \multicolumn{1}{l}{ F } & Sig. \\
1 & Regression & 360.728 & 2 & 180.364 & 880.843 & $.000^{\mathrm{b}}$ \\
& Residual & 11.672 & 57 & .205 & & \\
\hline
\end{tabular}

a. Dependent Variable: Employee_Productivity

b. Predictors: (Constant), Islamic_Work_Ethic, Islamic_Leadership

The hypothesis for the simultaneous effect is as follows:

$\mathrm{H}_{0}$ : Islamic Leadership and Islamic Work Ethic do not significantly affect Employee Productivity

$\mathrm{H}_{\mathrm{a}}$ : Islamic Leadership and Islamic Work Ethic significantly affect Employee Productivity

According to table 10, it is shown that the significance value (Sig.) of 0.000 is lower than
0.05. Thus $\mathrm{H}_{0}$ is rejected and $\mathrm{H}_{\mathrm{a}}$ is accepted. So, it can be said that simultaneously, Islamic Leadership and Islamic Work Ethic significantly affect Employee Productivity. The framework or the model obtained is shown in figure 4. 


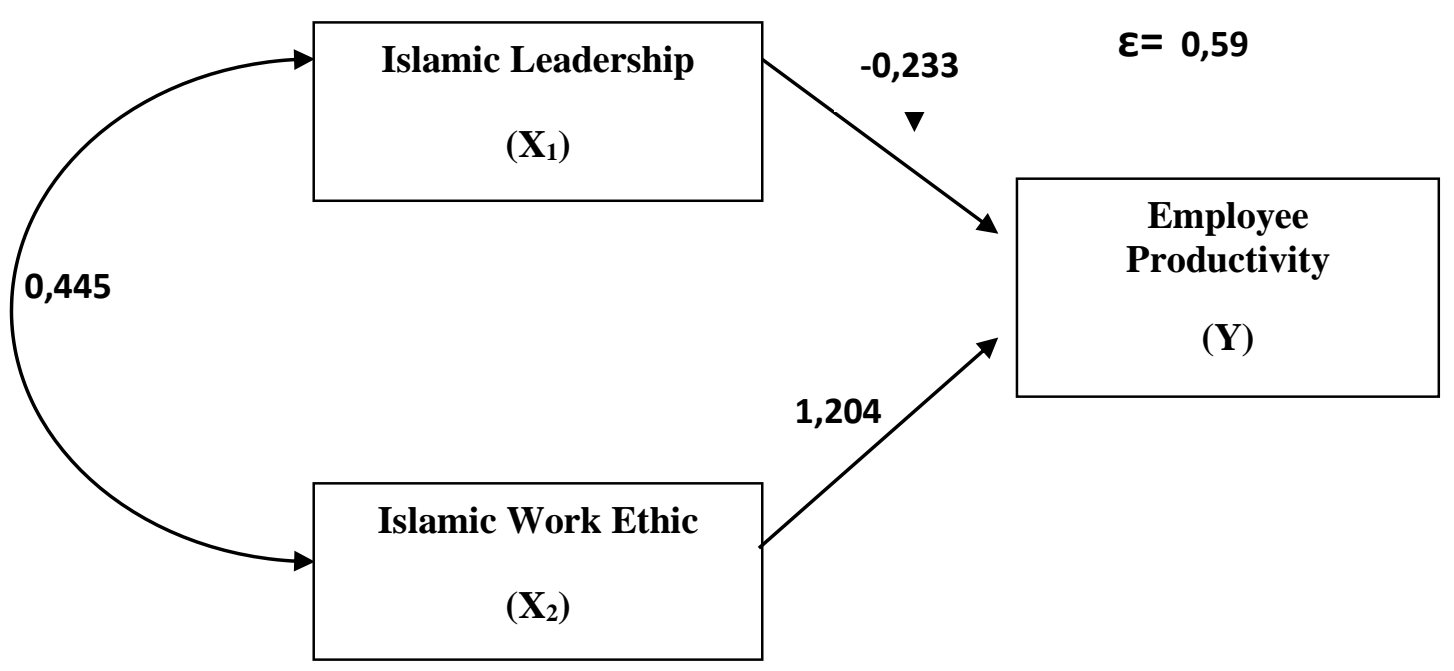

Figure 4 Relationship Structure of the Islamic Leadership and Islamic Work Ethic on Employee Productivity

From the figure above, this formulation can be constructed:

$$
Y=-0,233 Y=-0,233 X_{1}+1,204 X_{2}+\epsilon
$$

Where:

$\mathrm{Y} \quad=$ Employee Productivity

$\mathrm{X}_{1} \quad=$ Islamic Leadership

$\mathrm{X}_{2} \quad=$ Islamic Work Ethic

\section{CONCLUSION}

Islamic Leadership and Internalization of Islamic Work Ethic in sharia hotels in Bandung are categorized strong, indicating that the hotel leaders in these companies have a high level of honesty, trustworthy, intelligence, just, consensus in decision making, and discipline. These factors are both affect the productivity of employees of the sharia hotels in Bandung.

Partially, Islamic Leadership affects the employee productivity negatively. This perhaps because the employees do not see the difference between the general leadership and Islamic leadership, or they are not able to differentiate the characteristics of the Islamic leaders and nonIslamic leaders. Further, it can be explained that any leadership, either Islamic leadership or not, requires just, trustworthy, discipline and others. The variable which positively affects the employee productivity is the Islamic work ethic. Also, it is understandable that this factor is considered more important for the employees than the Islamic leadership.

Of the seven indicators measuring the Islamic leadership in sharia hotels in Bandung, the lowest score is for the variable of just. This indicates that the hotel leaders are not able to provide fairness to the employees. Thus, the leaders should evaluate the practice which is considered unfair. The leaders may provide a suggestion box or open communication so this issue can be overcome and will not affect the performance of employees.

The leaders of the sharia hotels should also lead the hotels by upholding the Islamic values in order to improve the trust of the employees. If the 
Jurnal Bisnis dan Manajemen, Volume 19, No. 2, September 2018, p. 122-139

employees have the high trust in their leaders implementing Islamic values, their productivity will improve, too.

Regarding the internalization of work ethic, employee creativity should be developed. To do this, the hotels may conduct training, counseling, open discussion, knowledge sharing session, and task-force formation.

For increasing employee productivity, especially the efficiency of the resources, the sharia hotels may uphold the reward and sanction program. The reward can be given as motivation to those who can use the resources efficiently.

\section{REFERENCES}

Ahmad, S., \& Owoyemi, M. Y. (2012). The Concept of Islamic Work Ethic: An Analysis of Some Salient Points in the Prophetic Tradition. International Journal of Business and Social Science, 3(20), 116-123. Retrieved from http://repo.uum.edu.my/7440/

Al- Ghazali, M. (2005). Akhlak Seorang Muslim. Kuala Lumpur: Victory Agencie.

Ali, A. (1992). Islamic work ethic in Arabia. Journal of Psychology, Vol. 126 No. 5.

Ali, A. J., \& Al-Owaihan, A. (2008). Islamic work ethic: A critical review. Cross Cultural Management: An International Journal, 15(1), 5-19.

https://doi.org/10.1108/13527600810848791

Business Dictionary. (2018). What is work ethic? definition and meaning. Retrieved September 29, 2018, from http://www.businessdictionary.com/definitio n/work-ethic.html

Chookaew, S., chanin, O., Charatarawat, J., Sriprasert, P., \& Nimpaya, S. (2015). Increasing Halal Tourism Potential at Andaman Gulf in Thailand for Muslim
Country. Journal of Economics, Business and Management, 3(7), 739-741. https://doi.org/10.7763/JOEBM.2015.V3.277

El-Kot, G. A., \& Burke, R. J. (2014). The Islamic work ethic among employees in Egypt. International Journal of Islamic and Middle Eastern Finance and Management, 7(2), 228-235. https://doi.org/10.1108/IMEFM09-2013-0103

Hakim, A. (2007). Kepemimpinan Islami (1st ed.). Semarang: Unissula Press.

Kemenpar. (2015). Ranking Devisa Pariwisata 2009-2013. Retrieved August 29, 2018, from http://www.kemenpar.go.id/userfiles/file/Ran king Devisa Pariwisata 2009 - 2013.pdf

Manan, S. K., Kamaluddin, N., \& Puteh Salin, A. S. A. (2013). Islamic work ethics and organizational commitment: Evidence from employees of banking institutions in Malaysia. Pertanika Journal of Social Science and Humanities, 21(4), 1471-1489.

Nawawi, H., \& Hadari, M. M. (2012). Kepemimpinan yang Efektif. Yogyakarta: UGM Press.

Rizk, R. R. (2008). Back to basics: An Islamic perspective on business and work ethics. Social Responsibility Journal, 4(1), 246-254. https://doi.org/10.1108/17471110810856992

Rokhman, W. (2010). The Effect of Islamic Work Ethics (IWE) on Work Outcomes. Electronic Journal of Business Ethics and Organization Studies, 15(1), 21-27. https://doi.org/10.4103/1817-7417.104699

Sedarmayanti. (2009). Sumber Daya Manusia Dan Produktivitas Kerja. Bandung: Mandar Maju.

Simanjuntak, P. J. (1985). Pengantar Ekonomi Sumber Daya Manusia. Jakarta: LP- FE UI.

Sugiyono. (2003). Statistik untuk Penelitian. Bandung: CV Alfabeta.

Tasmara, T. (2002). Membudayakan Etos Kerja Islami. Jakarta: Gema Insani Press.

Ya'qub, H. (1983). Etika Islam Pembinaan Akhlakqul karimah (suatu pengantar). Bandung: CV Diponegoro. 